\title{
A HADMŰVELETI TERVEZÉS TÖRTÉNETE ÉS A FRANCIA HADMŰVELETI MÜVÉSZET AZ INDOKÍNAI HÁBORÚBAN
}

\author{
DOI: 10.35926/HSZ.2021.1.7
}

ÖsszEFOGLALó: A hadmüveleti szintü tervezés a hadtörténelmi kutatások szempontjából egy viszonylagosan rövid időszakot jelent, és szükebb értelemben véve a 20. századra korlátozódik. A második világháború időszakára a hadmüveleti szint nagy jelentőséget kapott, és több eltérő koncepció jelent meg, amely különbségek a hidegháborús megosztottság során a két tömb vezető katonai nagyhatalmainak eltérő tapasztalatai, rendelkezésre álló erőforrásaiés céljai alapján csak még jobban elváltak egymástól. A hidegháborút követően az alacsony intenzitású müveletek elterjedésével a hadmüveleti szint ismét háttérbe szorult. Napjainkban, amikor az átalakuló biztonságpolitikai környezetben az aszimmetrikus konfliktusok mellett újra megjelent a globális nagyhatalmi és a regionális hatalmi vetélkedés, a hadmüveleti szint ismét elötérbe került. A több évtizedes kihagyás után logikus, hogy az újraértelmezés során elöször a hadtörténelmi példák megismerésével érdemes kezdeni. Az indokinai háború során a hibás francia stratégiai gondolkodás és az abból egyenesen következő hiányos, gyakran kidolgozatlan, sőt sürün változó stratégiai koncepciók hatására a hadmüveleti és a harcászati szint jelentösége megnövekedett, amire a sajátos földrajzi viszonyok csak ráerősítettek. A tanulmány célja, hogy bemutassa a háború során a müveleti szintek közötti tervezés viszonyait, kiemelve a hadmüveleti szint jelentőségét.

KULCSSZAVAK: hadmüveleti szint, tervezés, indokínai háború, hadtörténelem

\section{BEVEZETÉS}

A 19. század vége mind a hadseregek, mind a tudományok, mind az átlagemberek életében nagy változást hozott. A természettudományok, az orvoslás, a mezőgazdaság hatására az életkörülmények jelentősen javultak, így egyre többen érték meg a felnőttkort és tolódott ki az átlagéletkor. ${ }^{1}$ A hadseregek szempontjából ez nagyszámú, nyilvántartott, katonának alkalmas korosztályok megjelenését jelentette. A nehéz- és a vegyipar fejlődéséből következett, hogy ezeket a tömegeket egyre hatásosabb és nagyobb pusztító erejü fegyverekkel tudták fölszerelni. A vasúti és a folyami közlekedés, valamint a kommunikáció forradalma bezárta a kört, és fizikailag is lehetővé tette a nagy létszámú tömeghadseregek mozgósítását - amiért a század végén már a porosz mintára szervezett, speciálisan felkészített vezérkarok feleltek. ${ }^{2}$

\footnotetext{
${ }^{1}$ Life expectancy in France. https://www.ined.fr/en/everything_about_population/graphs-maps/interpretedgraphs/life-expectancy-france/ (Letöltés időpontja: 2019. 11. 08.)

2 Csikány Tamás: Az európai hadművészet a harmincéves háborútól a XIX. sz. végéig. ZMNE, Budapest, 2001, 115-117. https://nkerepo.uni-nke.hu/xmlui/bitstream/handle/123456789/15007/cst_europai_hadmuveszet_a_ harminceves_haborutol.pdf;jsessionid=4B1B758FEC946D670F33FA5FD4427CA5? sequence $=1$ (Letöltés időpontja: $20 \overline{2} 0.08 .24$.)
} 
Ezt a modern haditechnikai és ipari fejlödést azonban csak megkésve követte a katonai gondolkodás, a hadmüvészet fejlődése, hiszen a kor vezérkari főnökei - szinte kivétel nélkül a milliós hadseregekkel még jórészt a napóleoni, vagy tágabb értelmezésben 19. századi nagy, döntő csatákat keresték. ${ }^{3}$ Ezekre a nézetekre azonban rácáfolt az első világháború, amely egy rövid mozgó háborús időszakot követően brutális anyag- és állásháborút eredményezett. Az arcvonalak megmerevedése után a háború központi kérdésévé a tüzérséggel támogatott áttörés és az azt követő siker kifejlesztése, valamint az azt megakadályozni próbáló tartalékok bevetése közötti versenyfutás váltak. A nyugati hadszíntéren az áttörés eléréséhez szükséges volt a megfelelő létszámú, felszerelésű és támogatású csoportosítások, valamint kellő méretü tartalékok létrehozása, amely szélességében, de föleg mélységében meghaladta a harcászati szintủ vezetés és tervezés képességeit, de még nem érte el a teljes hadszínterekre kiterjedő hadászati tervezők szintjét. Azért, hogy ezt kezelni tudják, eleinte gyakran ad hoc törzseket hoztak létre, amelyek egy-egy hadműveletre jöttek létre, és annak a sikerességéért feleltek, vagy egy parancsnokság alá a rendszeresítettnél nagyobb erőket rendeltek - ezek tekinthetők a hadmüveleti vezetési szint első mai értelemben vett megjelenéseinek. ${ }^{4}$

Az első világháborút követően a szovjet terminológiában jelent meg először tudatosan a hadmüveleti művészet mint a hadászati és a harcászat közötti szint. ${ }^{5} \mathrm{~A}$ fogalom a két háború között virágzó szovjet hadtudomány eredménye, amely a 19. században gyökerezett, de az első világháború, és különösen az azt követő lengyelországi és polgárháborús hadmüveletek, sajátos tapasztalataiból született meg. A szovjet terminológia tehát az első megjelenés, amely főleg az alkalmazott erőkön és a müveleti terület méretén alapszik, és napjainkig a hadmüveleti művészet alkalmazásának és kutatásának az egyik legfontosabb iskoláját jelenti. A hadmüveleti vezetési szint a hadászati (rész-) célok elérésének érdekében egybefogta a harcászati szint ütközeteit és csatáit egy-egy hadmüvelet vagy nagyobb müvelet sikere érdekében, és azok támogatására saját erőforrásaival rendelkezett. ${ }^{6}$

A szovjet koncepció alkalmazásának kipróbálására a második világháborúban került sor, ahol az összfegyvernemi hadsereg - és az összhaderőnemi front (hadseregcsoport) müveletei jelentették a hadmüveleti szint sikeres próbáját. A frontok számára hadmüveleti irányokat jelöltek ki, amelynek érdekében vagy önállóan, vagy más frontokkal együttmüködve tevékenykedtek. A tapasztalatok feldolgozásából alkották meg azt a hidegháborús szovjet doktrínát, amely a Varsói Szerződés államaiban is a szovjet típusú hadmüveleti gondolkodást vezette be.

Az amerikai, tágabb értelemben vett nyugati terminológia később született meg - a második világháborúban a nyugati szövetségesek számára a müvelettervezés a napjainkban is ismert, mai elnevezéssel többnemzeti (multinational) együttmüködés keretein belül valósult meg. Ez és a nemzetek eltérő politikai céljainak megvalósítása egy, már a stratégiai tervezéstöl kezdve kompromisszumos döntéshozatal eredménye volt, amely során a célok kijelölése sem csak katonai, hanem politikai érdekek és egyezségek mentén zajlott. A legmagasabb

3 Uo. 117.

4 Csikány Tamás: Az első világháború eseményei és hadmüvészete. ZMNE, Budapest, 2010, 42-43.

5 Wilson C. Blythe: History of Operational Art. Military Review, 11-12. 2018., 40. https://www.armyupress. army.mil/Portals/7/military-review/Archives/English/ND-18/Blythe-Operational-Art.pdf(Letöltés időpontja: 2019. 11. 05.)

6 Michael D. Krause: Operational Art Origins, Evolution and Application. A Forecast. In: J. Thomas Clayton: Operational Art and Analysis. CMH, 1991, III-4. https://www.researchgate.net/publication/232887426_The evolution_of_Soviet_operational_art_The_significance_of_'strategic_defense'_and_'premeditated_defense' in_the_conduct_of_theatre-strategic_operations (Letöltés időpontja: $2019.11 . \overline{0}$. 08. . 
politikai szint tehát beleszólt a müvelettervezésbe is, ${ }^{7}$ és a politikai célok egyeztetésének fontossága felülmúlta a legszükebb értelemben vett katonai szintek közötti koordinációt is.

Az angolszászok összhaderőnemi integrációja sem érte el a szovjet szintet. A nyugati szövetséges légierő például önálló stratégiai - és ezzel együtt közvetetten gazdasági és politikai - célokat is szolgált, és a feladatkörét csak kiegészítette a szárazföldi erők számára nyújtott támogatás. Ezzel szemben a szovjet oldalon a frontok rendelkeztek szervezetszerü légi hadseregekkel, amelyeknek képességeit a saját céljaik elérésére fordíthatták, így összhaderőnemi szempontból szabadabban tervezhettek müveleteket.

Ezekből a körülményekböl következik, hogy a második világháborút követően létrehozott NATO később és döntően más tapasztalatok alapján határozta meg a fogalmat. Az amerikai és ezen keresztül a NATO hadmüveleti szintje a szovjettől eltérően kevésbé a szigorúan vett katonai müveleti cél elérését helyezte a középpontba, hanem megjelenik a stratégiai, azon keresztül a politikai cél elérésének igénye is. Napjainkban erre a folyamatra világít rá a NATO átfogó müvelettervezési utasítása $\left(\mathrm{COPD}^{8}\right)$, amely számtalan, a tisztán katonai célok mellett megjelenő szempontot vesz figyelembe a tervezés során.

Bár az amerikai hadműveleti művészet a második világháborús alapokon indult fejlődésnek, de az 1960-as évek közepén megszületett szovjet teóriákra válaszul változáson esett át. A csak katonai értelemben vett hadmüveleti szint legmarkánsabban a manőverközpontú 9 doktrínák - például az AirLand Battle az 1980-as években ${ }^{10}$ - megszületésekor jelent meg az amerikai tervezésben. Az úgynevezett manőverdoktrína legjelentősebb és legismertebb próbájára a Sivatagi vihar hadmüveletben került sor, amikor az amerikai vezetésủ és túlsúlyú nemzetközi koalíciós erők gyors győzelmet arattak az iraki erők fölött.. ${ }^{11}$

\footnotetext{
${ }^{7}$ A szovjet oldalon a politikai vezetés centralizáltsága, Sztálin vezetési stílusa más módon szólt bele a katonai vezetésbe. A célok kijelölése, határidők szabása propagandisztikus célokat szolgált, amit kiegészített az erőforrások (központi tartalékok) fölött gyakorolt hatalom és a katonai vezetők versenyeztetése is. Ez jellegében eltért a nyugati szövetségesek, azaz egyenrangú felek közti kényszerü kompromisszumos rendszertől, amely a katonai vezetőkre ott inkább egy külső, míg a szovjet rendszerben inkább egy belső politikai nyomásgyakorlást jelent.

${ }^{8}$ Allied Command Operations - Comprehensive Operations Planning Directive - COPD Interim V2.0. NATO SHAPE, 04. 10. 2012. https://www.cmdrcoe.org/download.cgf.php?id=9 (Letöltés időpontja: 2019. 11. 04.)

${ }^{9}$ Ugyanakkor a két háború közötti, a manővereket középpontba helyező harc megvívását preferáló szovjet teoretikusok mélyhadmüveleti elméletével kapcsolatos bizonyos jegyek is fölfedezhetők a doktrínán. Blythe: i. m. 7.

${ }^{10}$ A név is mutatja, hogy a doktrína a szoros szárazföldi és légi haderőnemi együttműködésre épült, amelyhez hasonló mértékben ez sem az elötte, sem az utána született szabályzatokban nem realizálódott. A doktrína a feltételezett szovjet eljárásokat szem előtt tartva, azokból nagyban merítve született meg, és a korszak nyugati katonai gondolkodása által újra felfedezett manőverekre épített. Többek közt ez a „manővergondolkodás” hívta életre a nagyrészt ma is használatban lévő eszközöket, mint például az M2/M3 Bradley harcjárműveket, az M1 Abrams harckocsikat és az A-10 repülögépeket. Az első (FM 100-05, 1982), majd második (FM 100-05, 1986) AirLand Battle doktrína kidolgozásában meghatározó szerep jutott egy magyar származású amerikai fötisztnek, Wass Hubának.

${ }^{11}$ Az amerikai terminológia sem egységes, a haderőnemi és az összfegyvernemi kiadványok alapján megkülönböztetik a katonai értelemben vett hadmüveleti vezetési szintet (Operational Level of War/Warfare) a hadmüveleti művészettől (Operational Art). Az első egy deduktív folyamat, amely hidat képez a hadászati és a harcászati szintek között, egyszerúen célokat bont le részcélokká, amíg azok elérhetök nem lesznek harcászati mozzanatokkal, amelyek hadmúveletté (operations) állnak össze. A második tulajdonképpen nem szintfüggő, hanem egy kreatív problémamegoldó folyamat, amely során a tervezésben részt vevők a stratégiai célokhoz módszereket és erőforrásokat rendelnek, amiből végső soron megszületik a hadmüveleteket összefogó és a stratégiai cél elérését biztosító hadjárat (campaign). Jelen tanulmánynak nem célja ezek között különbséget tenni, ezért azok szinonimaként szerepelnek. DOD Dictionary of Military and Associated Term as of 2019. 159-161. https://www.jcs.mil/ Portals/36/Documents/Doctrine/pubs/dictionary.pdf (Letöltés időpontja: 2019. 11. 05.)
} 
Napjainkban tehát az amerikai müveleti tervezéssel kapcsolatos gondolkodást döntöen az öbölháborús tapasztalatok, az utoljára végrehajtott nagy, konvencionális múveletek határozzák meg. Az abban részt vevő - és akkor még - ifjú, jellemzően csapatnál szolgáló tisztikar tagjai életkoruknál fogva még szolgálatban vannak, és meghatározzák a katonai felső vezetés összetételét. Az utánuk következő tisztek generációi azonban már szinte nem vettek részt másban, csak az iraki vagy az afganisztáni hadszíntér müveleteiben, ahol a rövid konvencionális szakaszt követö időszakot a stratégiai szintü hatást kifejtő különleges erők nagyarányú alkalmazása, a teljes haditechnikai és létszámfölény, valamint a teljes légi uralom jellemezte, illetve a francia és a brit gyarmati háborús tapasztalatokra épített felkelésellenes $\left(\mathrm{COIN}^{12}\right)$ doktrínák kerültek elötérbe. A felnövő tisztek egész korosztályai számára a hadmüveleti szintű vezetés a hadszíntérért felelős földrajzi (Combatant Command) és/vagy összhaderőnemi, esetleg koalíciós (Joint/Task Force) szintű parancsnokságok távoli képében volt jelen, nem pedig egy-egy hagyományosan vett hadmüveletért felelős parancsnokság képében. A stratégiai szint és a harcászati szint közel került egymáshoz - például a különleges erők alkalmazásán és hatásán keresztül, vagy a konvencionális müveletekhez mérten csekély méretű veszteségek nemzetekre gyakorolt hatásán át -, a hadmüveleti szint pedig jelentőségét vesztette, és korlátozott koordinációs, nem pedig a korábbihoz hasonló önálló erőforrásokkal rendelkező vezetési és tervezői feladatkört jelentett.

\section{A FRANCIA HADMÜVELETI MŰVÉSZET TÖRTÉNETE}

A francia hadműveleti művészet hagyományosan a forradalmi és a napóleoni háborúk időszakára vezeti vissza a gyökereit. Bár a hadtest mint szervezési lépcső sikeresen bizonyított a hadjáratokban, a francia hadsereg tisztikara egészen a francia-porosz háborúig nem foglalkozott különösebben a hadmüveleti szintű kérdésekkel. Az elszenvedett vereség a porosz hadsereg szervezési eljárásait igazolta. A franciák először állandó szervezetként létrehozták a békeidős hadtestek, majd néhány évvel később a tábori hadseregek törzseit, és elkezdték azokat vezérkari iskolát végzett jó képességü tisztekkel föltölteni. 1913-tól a francia hadseregben már szabályzatba foglalták a hadseregcsoportok létrehozását és meghatározták azok várható tevékenységét is. ${ }^{13}$

Az első világháború előestéjén a franciák már szervezetileg és haditechnikailag a kor színvonalán álló hadsereggel rendelkeztek, de a gondolkodást és a müvelettervezést még a napóleoni elvek határozták meg. A támadást és a manőverezést a védelemnél fontosabbnak tartották (l'offensive á outrance), ${ }^{14}$ ugyanakkor nem vették figyelembe a bekövetkezett haditechnikai fejlődést és annak várható hatásait. A háború előrehaladtával a francia haderő a céljait mindinkább a tüzérségre támaszkodva igyekezett elérni, ami 1917-1918 során Nivelle és Pétain tábornokok nevével fémjelzett időszakban csúcsosodott ki. ${ }^{15}$ Pétain tábornok

12 Counter-Insurgency.

${ }^{13}$ Robert A. Doughty: French Operational Art - 1888-1940. In: Michael D. Krause - Cody R. Phillips (eds.): Historical Perspectives on the Operational Art. Center of Military History, United States Army, Washington, D.C., 2005, 77. https://history.army.mil/html/books/070/70-89-1/cmhPub_70-89.pdf (Letöltés idöpontja: 2019. 11. 05.)

${ }^{14}$ Elizabeth Kier: Imagining War: French and British Military Doctrine between the Wars. Princeton Studies in International History and Politics, Princeton University Press, 1999, 41.

15 Pétain tábornok a haderő vezetésének átvételét követő egyik első direktívájában a nagy offenzívák helyett korlátozott támadások indítását írta elö, amelyben a tüzérség szerepét maximalizálni, a gyalogságét pedig minimalizálni igyekezett. A németek ezzel ellentétben a gyalogság szerepét növelték meg a háború második felében: a speciálisan felszerelt és felkészített gyalogos rohamcsapatok az ellenség soraiba beszivárogva készítették elő a főerők támadását. Doughty: i. m. 82-86. 
korlátozott célokért indított támadásokat, egyiket a másik után, hogy felörölje az ellenséget - amint annak tartaléka beavatkozott a harcokba, a támadást leállította, hogy saját csapatait megóvja. Ez a lassú, módszeres, súlypontját és irányát többször áthelyező támadási eljárás (la bataille conduite), ${ }^{16}$ valamint a tüzérségi tüz koncentrációjának fontosságát kihangsúlyozó, magas szintről irányított és tervezett tüzcsapások sorozatával sikert elérni kívánó hadmüvészet ezután évtizedekre meghatározta a francia katonai gondolkodást. ${ }^{17} \mathrm{~A}$ francia hadmüveleti tervezési és vezetési szint lett a két világháború között, valamint az 1940-es küzdelmek során a legfontosabb vezetési szint, amely szükségtelenül átvett sok feladatot az eközben háttérbe szorított harcászati szinttől - míg a hadászati szintü tervezést a szövetségesek közti koordináció dominálta. ${ }^{18}$

Ez a gondolkodás, amely a hangsúlyt hadtest- vagy magasabb szintü kötelékekre helyezte, valamint a tüzérség, azon belül is a nagy hatótávolságú eszközök alkalmazását preferálta, alapvetően egy statikus küzdelem megvívására volt alkalmas. A harcászati, de főleg a hadmüveleti mozgékonyságot a lassan és az infrastruktúra függvényében mozgatható, valamint a logisztikai rendszert súlyosan megterhelő nehéztüzérség favorizálása tovább korlátozta. A francia koncepció - amely a tüzérséget kézben tartó hadsereg-, illetve hadtestvezetési szintet helyezte előtérbe a harcászati szintü vezetéssel szemben - 1940-re minden alulról jövő kezdeményezést elutasítóan rendkívül merevnek számított. Ez a koncepció a harcászati és hadmüveleti mozgékonyságot, valamint az ahhoz kapcsolódó decentralizált vezetési koncepció előnyeit maximalizáló német haderővel szemben látványosan alulmaradt, és Franciaország gyors háborús vereségének egyik legföbb oka lett.

A francia tervezés a német keskeny és sebezhető arcvonalrészen indított támadással szemben kifejezetten széles szakaszon megindított támadással számolt, amely hasonlóságot mutatott a szovjet mélyhadmüvelet elméletével, de attól eltérően csak kis mélység elérését tűzte ki célul. ${ }^{19}$ A páncélosok fejlesztési irányát is ez a relatíve kis mélységü tevékenység határozta meg, és bár a légierő számára nagyobb mélységben is jelöltek ki célokat, a szárazföldi haderőnemmel folytatott együttműködése súlyos hiányosságokat mutatott. Még súlyosabb volt azonban az, hogy az ellenség müveletei tempóját és céljainak kijelölését is a saját lassú és kis mélységü hadmüveleti feladataikhoz hasonlónak gondolták.

A francia katonai vezetés tehát ezeken az elveken szocializálódott, a tüzérség és a kiépített védelem erejében bízott, amelyet egy szigorúan tekintélyelvü vezetési rendszerrel támogattak meg. Ez a sok évtizedes rugalmatlan irányításhoz szokott merev gondolkodás kifejezetten hátrányosnak bizonyult, amikor Indokínában az ,,arcvonal nélküli háborúban” szembekerültek a Viet Minh harcosaival.

\footnotetext{
16 Kier: i. m. 40.

17 A hadtörténelmi kutatások és esettanulmányok fókuszába is az ehhez hasonló, késői háborús események kerültek. Különösen fontos volt a két háború közötti hadmüvészet-történet oktatásában a montdidier-i csata (1918. 08. 08-10.), ahol a francia erők elérték a német tartalékok idő előtti bevetését, ezáltal az arcvonal egy más pontján komoly sikereket értek el. Ez a csata vált a második világháború kezdetére a módszeres francia hadmüveleti tervezés sikerének mintájává.

18 Horváth Csaba alezredes: Az 1940-es német-francia háború stratégiai-hadászati és hadműveleti kérdései. Seregszemle, 2013/2-3., 279. https://honvedelem.hu/files/files/39133/seregszemle-2-3_internet.pdf (Letöltés időpontja: 2019. 11. 03.)

19 Doughty: i. m. 93.
} 


\section{A FRANCIA KATONAI VEZETÉS INDOKÍNÁBAN}

A francia katonai felső vezetés életkorának függvényében tehát döntően a két világháború közötti hadmüveleti doktrínák alapján szerezte meg legfontosabb tapasztalatait. A háborút követően a tábornoki kar azonban nem volt egységes - míg egyesek a módszeres múveletek teljes sikertelenségét látták az 1940-es sokkoló vereségben, addig mások csak az elmélet rossz gyakorlati megvalósítását és az egyéni hibákat okolták. A tábornokok között újabb törésvonalat jelentett, hogy egy részük hosszú hadifogságból tért vissza, míg mások a kollaboráns rendszer kiszolgálói voltak, esetleg De Gaulle mögé álltak be. A megosztottságot csak fokozta, hogy milyen háborús tapasztalatokkal rendelkeztek: az ellenállásban dolgoztak, ${ }^{20}$ vagy Észak-Afrikában sivatagi körülmények között gyarmati katonákat irányítottak, esetleg angol és amerikai felszereléssel, szövetséges együttmüködés (és vezetés) mellett szerezték azokat az európai hadszíntéren. Mindezek tetejébe néhányuk nagy nemzetközi elismertségnek és népszerüségnek örvendett - például De Lattre ${ }^{21}$ vagy Leclerc ${ }^{22}$ tábornokok -, ami a merev és tekintélyelvü francia hadseregben hatalomhoz szokott emberek egy részében egyszerüen féltékenységet váltott ki. Elmondható tehát, hogy a francia katonai felső vezetés mind tapasztalatában, mind gondolkodásmódjában meglehetősen heterogén volt.

Az 1940-es döntő vereségből és évekig tartó megaláztatásból éppen csak kilábaló, rendkívül szerteágazó tapasztalatokkal rendelkező, gyakran csalódott és személyes ellentétektől ${ }^{23}$ terhelt katonai vezetői réteg mellett sodródott a világháborús újjáépítés terheit nyögő Franciaország egy távol-keleti gyarmati háborúba.

A második világháborút megelőzően a Francia Idegenlégióval kiegészített francia fegyveres erők a hagyományosnak mondható haderőnemi és fegyvernemi bontás mellett az állomáshelyük és tulajdonképpeni feladatrendszerük alapján európai (métropole, vagyis anyaországi) és gyarmati (colonial) csapatokra is feloszthatók voltak.

A publikáció témáját érintő indokínai hadszíntéren állomásozó gyarmati alakulatok - bár nevükben szintén ezred és zászlóalj szerepelt - nagyban különböztek az európai kötelékek felépítésétől, sokkal inkább ernyőszervezetek voltak. Területi alapon szerveződtek, tehát egy-egy (al-) szektornyi müveleti területért egy gyarmati század vagy zászlóalj felelt, fölöttük zónák (ezredek/dandárok), majd regionális területi parancsnokságok (név alapján hadosztályoknak megfelelő kötelékek) feladata volt a rendfenntartás, valamint egy sor gyarmati adminisztrációs munka elvégzése is, amelyek egyébként nem számítottak tipikus katonai feladatoknak. ${ }^{24}$ Ezek a területi parancsnokságok Kokinkína, Annam és Tonkin területén települtek, és nem

${ }^{20}$ Forgács Balázs: A második világháború partizánharcai és ellenállási mozgalmai Európában. Hadtudományi Szemle, 2018/3., 51. http://real.mtak.hu/86888/1/18_3 hm_forgacs_balazs.pdf (Letöltés időpontja: 2019. 11. 05.)

${ }^{21}$ Jean de Lattre de Tassigny (1899-1952) a francia hadsereg egyik legnépszerübb tábornoka, a második világháború végén az amerikaiak által fölszerelt és részben amerikai egységekből álló, Németországba betörő francia 1. hadsereg és később a francia megszálló erők vezetője volt.

22 Philippe Leclerc de Hauteclocque (1902-1947) tábornok a De Gaulle oldalán Párizst 1944 augusztusában fölszabadító francia 2. páncéloshadosztály parancsnoka volt.

23 Több, hadifogságból visszatért idősebb tiszt nehezményezte, hogy a második világháborúban a Szabad Francia Erők soraiban harcoló fiatalabb kollégáik ,átlépték őket”, vagyis magasabb rendfokozatra tettek szert a háborús években. Ez a tény rendkívüli sértettséget váltott ki belölük, főleg amikor a bonyolult indokínai hadszíntéren alá-fölé rendeltségi viszonyba kerültek velük, ami a kiadott parancsaik sajátságosan értelmezett végrehajtását, sőt felülbírálását is eredményezte.

${ }^{24}$ Peter D. Jackson: French Ground Force Organizational Development for Counterrevolutionary Warfare between 1945 and 1962. Thesis, Army Command And General Staff College, Fort Leavenworth KS, 2005, 24. https:// apps.dtic.mil/dtic/tr/fulltext/u2/a436931.pdf (Letöltés időpontja: 2019. 11. 02.) 
állandó létszámú alárendelt alakulatokkal rendelkeztek, hanem az alájuk rendelt körzet méretének és fontosságának megfelelő számú, jellemzően kiépített helyőrségekben elhelyezett zászlóalj és ezred volt az alárendeltségükben. ${ }^{25}$ Az egész katonai-adminisztrációs struktúrát egy névleg hadtestszintü kötelék fogta össze, amely Saigonban települt.

Ez a szervezet a japánokkal történt megegyezésnek megfelelöen 1940-1945 között is fönnállt, de a gyarmati kötelékeket részben lefegyverezték és kevés funkciót hagytak meg nekik - nagy részüket passzivitásra, míg egy részüket gerillaharcra kényszerítve. Ez a helyzet egészen 1945 márciusáig nem változott, akkor a császári erők lerohanták a francia laktanyákat és hadifogságba ejtették a túlélőket. ${ }^{26}$

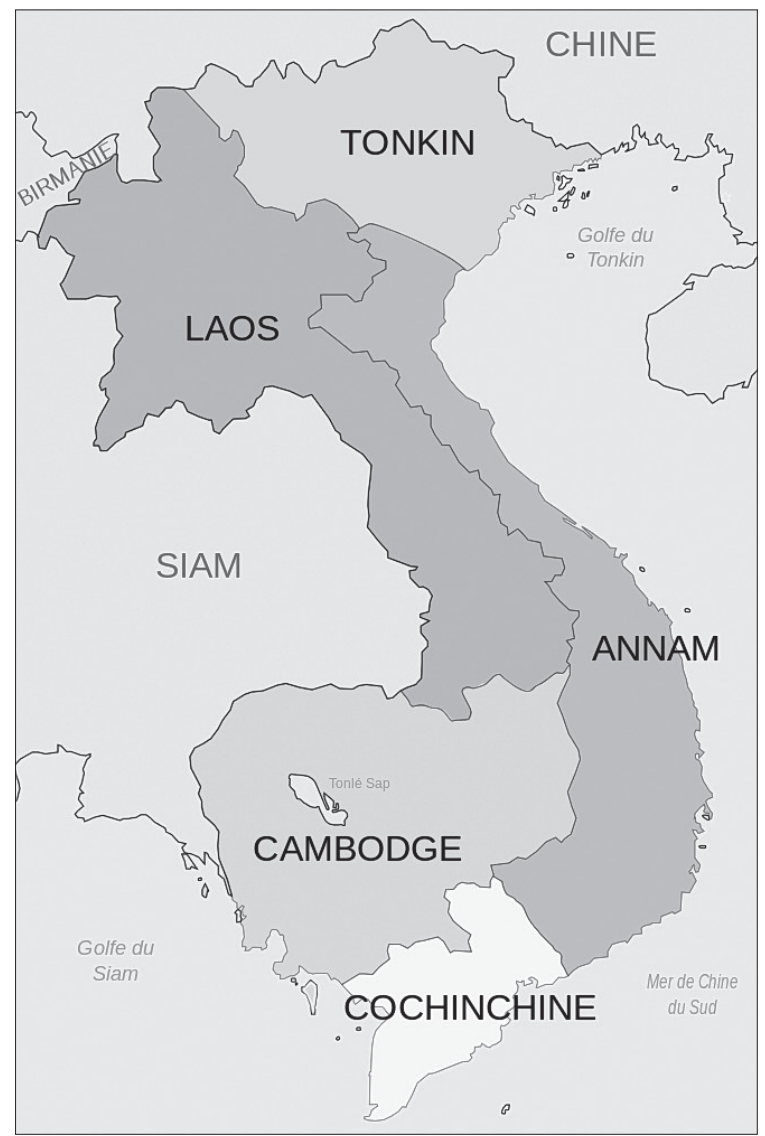

1. ábra Francia Indokina részei ${ }^{27}$

${ }^{25}$ A csapatok összetétele is változatos volt - jellemzően helyi katonák adták a gyarmati alakulatok gerincét, akiket francia tisztek vezettek. A fegyverzetük sem az első vonalbeli alakulatokéval volt egyenértékủ, hisz föleg a rendfenntartás tartozott a feladatkörükbe. Kevesebb volt a nehézfegyverek és a mozgó hadviselésre alkalmas eszközök száma is, amely a későbbiekben döntő hátránynak bizonyult mind a japánok, mind a Viet Minh ellen, amelyet a hadszíntér földrajzi sajátosságai csak tovább növeltek.

${ }^{26}$ Jackson: i. m. 33.

${ }^{27}$ Dong Nguyen: Un peu d'histoire du Vietnam - CAP sur L'ANNAM. Capannam Travel. https://capannam.com/ guide-pratique-vietnam/histoire-annam (Letöltés időpontja: 2019. 11. 05.) 


\section{A FRANCIA HADMŰVELETI VEZETÉS FELÉPÍTÉSE}

De Gaulle tábornok a nemzeti érdekeket szem előtt tartva már a második világháború utolsó évében, szövetségesi jóváhagyással elrendelte egy európai mintájú, tehát nem territoriális, hanem harcoló hadosztályokból álló hadtestszintű szervezet megalakítását, amelynek célja egyfelöl Francia Indokína visszafoglalása lett, másfelöl a franciáknak a szövetségesek felé teljesítendő csendes-óceáni szerepvállalásának keretét adta. Ez lett a Leclerc tábornok vezette Francia Távol-keleti Expedíciós Hadtest (Corps Expéditionnaire Français en ExtrêmeOrient, CEFEO), ${ }^{28}$ amely 1945 szeptemberében érkezett meg a számára kijelölt hadszíntérre. A háború 1954-es lezárásáig a CEFEO maradt a legmagasabb szintủ francia kötelék Indokínában, amelynek vezetője egyben a hadszíntér katonai parancsnoka is volt. Jellemzően a civil politikai-adminisztrációs feladatokat a kijelölt francia főképviselő látta el, de egyes ritka esetekben mindkét pozíciót ugyanaz a személy töltötte be - például De Lattre tábornok 1950-től haláláig.

A hadszíntéren a hadmüveleti vezetés megszervezésekor keveredett a korábbi gyarmati alapú területközpontú struktúra, a haderőnemi megosztás és a modern, funkció és feladat szerinti csoportosítás, sőt mindezek mellett az egyes fontosabb hadmüveletek vezetésére ideiglenes hadmüveleti szintü parancsnokságokat hoztak létre. ${ }^{29} \mathrm{Ez}$ a müveletek végrehajtása során meglehetősen kusza alá- és fölérendeltségi viszonyokat eredményezett, amit csak súlyosbított a korábban fölvázolt személyes ellentétek megléte. Ilyen elmérgesedett helyzetre példa a Dien Bien Phu-nál zajló csata és az egész régió sorsát befolyásoló vita a tonkini müveletek vezetésével megbízott René Cogny tábornok és elöljárója, a CEFEO parancsnoka, Henry Navarre tábornok között: Cogny kérte felmentését személyes összeférhetetlenségre hivatkozva, amit Navarre nem engedélyezett, és a szükséges erők rendelkezésére bocsátásának megtagadásával „hálált” meg. ${ }^{30}$

A hagyományos gyarmati rendszer mintájára 1946-tól a CEFEO hadosztályaiból megalakult a Távol-keleti Francia Erök (Troupes Françaises d'Extrême-Orient, TFEO) kötelékébe tartozó két legfontosabb területi parancsnokság: északon, Tonkin és Laosz területén az Észak-indokínai Francia Erök (Troupes Françaises d'Indochine du Nord, TFIN), délen pedig, Kokinkínában és Kambodzsában a Dél-indokínai Francia Erök (Troupes Françaises d'Indochine du Sud, TFIS). ${ }^{31}$

De Lattre tábornok vezetése idején (1950-1952) a CEFEO egy európai tábori hadsereg méretű szervezet volt, ahol a regionális szint hadtest-, a zóna hadosztály-, a szektor ezred/ dandár-, az alszektor pedig zászlóaljszintü felelősségi terület volt. A harcok intenzitásának

${ }^{28}$ Bizonyos szervezetelemzés-központú források a CEFEO fennállását csak 1945-1946-ra teszik. Ez részben igaz is, hisz az Európában harcoló hadtestek mintájára létrehozott CEFEO szervezete ekkortól teljesen átalakult a korábbi gyarmati-territoriális séma szerint. Mivel azonban másik csúcsszervezet nem jött létre helyette, és a CEFEO parancsnokai az összes Indokínában állomásozó erő parancsnokai maradtak, a hagyományos elnevezés (bár funkcióját elvesztette) megmaradt.

${ }^{29}$ Legjobb példa erre a Dien Bien Phu környéki mủveletek hadmüveleti irányítására megalkotott Északnyugati Hadmúveleti Csoport (Groupe d'Opération Nord-Ouest, GONO), amely egyszerre tartozott a hadszíntér-parancsnokság (CEFEO) és a regionális (tonkini) parancsnokság alárendeltségébe is.

${ }^{30}$ Martin Windrow: The Last Valley. Dien Bien Phu and the French Defeat in Vietnam. Cassel, London, $2005,472$.

31 A tévedések megelőzése végett szükségesnek tartom jelezni, hogy a TFEO elnevezés az indokínai hadszíntéren állomásozó francia katonák egészére vonatkozó gyűjtőkifejezés, nem pedig egy vezetési vagy területi szervezési szint. Az eredeti nyelvű források a TFEO rövidítést gyakran használják a CEFEO szinonimájaként, míg a TFIN és a TFIS két regionális parancsnokságot jelentenek. 
megfelelően a tonkini területeken állomásozó erők nagyobb létszámúak voltak, vagy egyes felelősségi területhez több köteléket rendeltek hozzá.

Ebben az időszakban a francia erőket átszervezték, és létrejöttek a Távol-keleti Szárazföli Erök (Forces Terrestres d'Extrême-Orient, FTEO) részét képezö új territoriális parancsnokságok. Ilyen hadmüveleti szintü parancsnokság volt a Tonkin területén zajló müveletekért felelős Észak-vietnámi Szárazföldi Erök (Forces Terrestres du Nord Vietnam, FTNV), a Kokinkína területén tevékenykedő Dél-vietnámi Szárazföldi Erők (Forces Terrestres du Sud Vietnam, FTSV), ${ }^{32}$ valamint az Annam területén megalakult a Közép-vietnámi és Felföldi Szárazföldi Erök (Forces Terrestres du Centre-Vientam et des Plateaux, FTCVP) parancsnokság. 1950 után a Francia Unió tagjaiként mind Laosz, mind Kambodzsa önálló területi parancsnoksággá vált, és Vietnámmal kiegészülve mindhárom ország fegyveres ereje a CEFEO alárendeltségébe került.

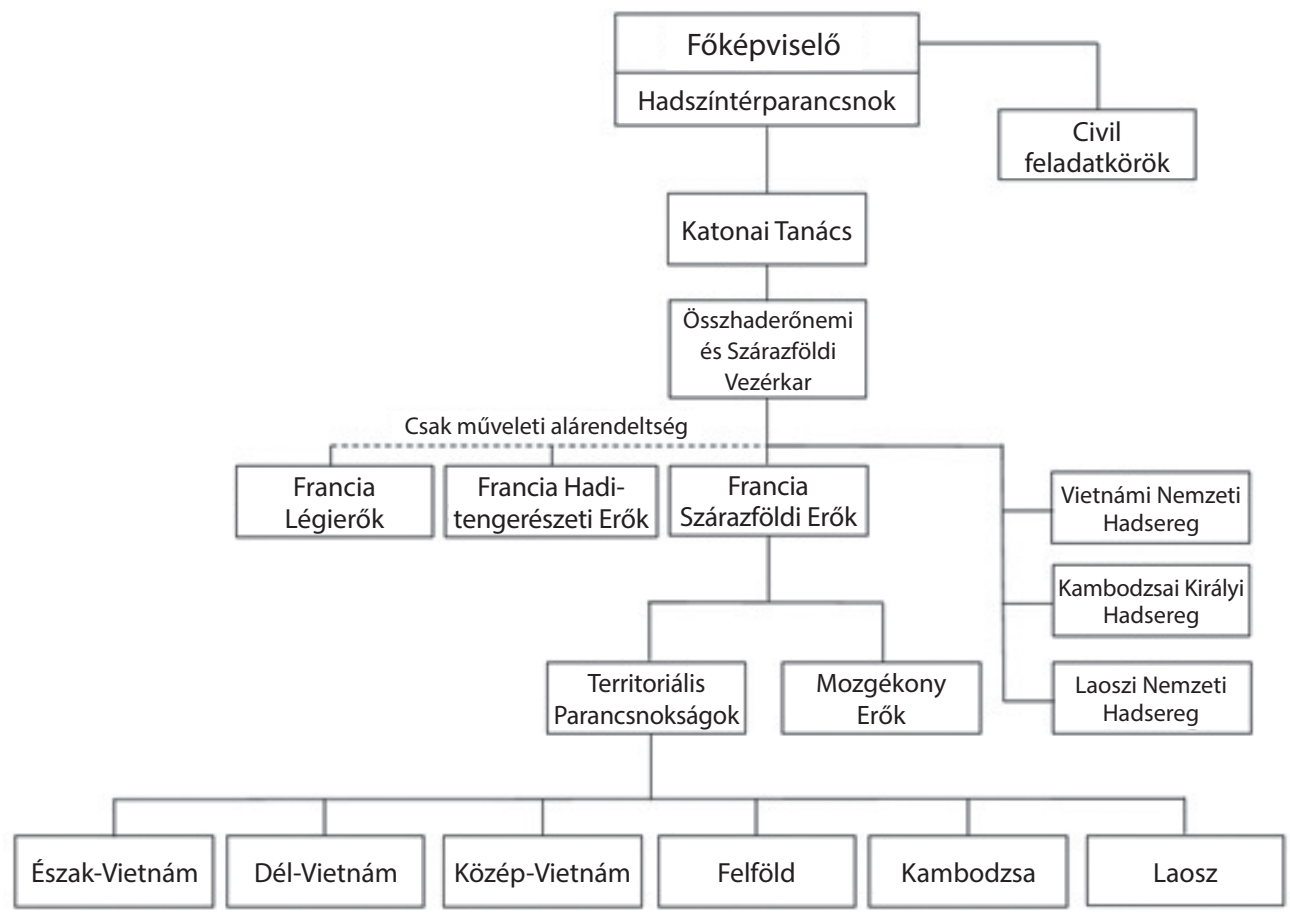

2. ábra A CEFEO szervezete 1952-ben ${ }^{33}$ (Szerkesztette a szerzö)

A regionális erők föleg statikus gyalogsági alakulatokból álltak, amelyek feladata a fontos terepszakaszok és települések megtartásából állt, ezért velük bármilyen támadó müvelet indítása szinte lehetetlen vállalkozásnak tünt - nem is beszélve a tartalékok kialakításának nehézségeiről. Ezekre válaszul a francia vezetés a mozgékony eröket, azaz a kevés számú páncélosalakulatot és a háború második felében megszervezett gépesített csoportokat (Groupement Mobile, GM) közvetlenül a FTEO vezetése alá rendelte, és a legkritikusabb helyeken vetette be.

\footnotetext{
32 Jackson: i. m. 53.

${ }^{33}$ Charles M. Shrader: A War of Logistics: Parachutes and Porters in Indochina, 1945-1954. Foreign Military Studies. University Press of Kentucky, Lexington, 2015, 15.
} 
A francia erők csapatainak igazi mozgékonyságát, a hadmüveleti tartalékot azonban az ejtőernyős csapatok (Troupes Aéroportées d'Indochine, TAPI) jelentették, amelyek egy északi és egy déli funkcionális parancsnokság köré szerveződtek - súllyal Tonkin területén. Ennek oka a légierő célba juttató képességének korlátozottságában keresendő. Ezzel a szárazföldi erök kötelékében is megjelent a territoriális szervezési elv mellett a funkció - jelen esetben a mozgékonyság - szerinti elkülönülés.

Ez a szervezési sajátosság és a mobil (gépesített és ejtőernyős) erők hadmüveleti szintű parancsnokságokhoz rendelése nem bizonyult szerencsés lépésnek - a területileg szerveződő vezetési szinteken a régiók vezetői - hadosztály-, később hadtestszintủ parancsnokságok voltak hivatottak a statikus, jellemzően kis logisztikai igényekkel rendelkező gyalogsági erőiket és a gyorsan mozgó, teljesen eltérö feladatkörre alkalmazható, különböző képességü és nagy ellátási igényt támasztó kötelékeket összehangolni, valamint azokat saját korlátozott erőforrásaikból saját rendszerükbe illesztve kiszolgálni. A helyzetet csak súlyosbította, hogy a támadó müveletek közben a mozgékony gépesített és ejtőernyős erők a kedvezőtlen terep ellenére is általában mélyen behatoltak az ellenség területére, ezáltal elszakadtak a saját statikus, kulcsterületeket őrző gyalogságtól, ami nagyban megnehezítette a vezetésüket és az ellátásukat. ${ }^{34}$

A légierő és a flotta erői saját hadmüveleti szintü, haderőnemi komponensparancsnokság alá voltak rendelve - Távol-keleti Légierő (Forces Aériennes en Extrême-Orient, FAEO) és Távol-keleti Haditengerészeti Erők (Forces Maritimes en Extrême-Orient, FMEO) -, ami bonyolultabbá tette az együttmüködést, ráadásul azok a saját, anyaországi vezérkari főnökeik felé is elszámolással tartoztak, különösen az északon jellemző nagyszámú folyami müvelet (Dinassaut ${ }^{35}$ ) során.

A CEFEO parancsnoka mindig a szárazföldi erőktől jött, a helyettese pedig a légierőtől - ennek ellenére az együttműködés a repülőgépek alkalmazásáról kialakított koncepciók miatt nem volt túl sikeres. A szárazföldi vezetés a repülőerőktől a saját müveletek közvetlen légi támogatását várta, míg a háború előrehaladtával amerikai technikával fölszerelt és amerikai mentalitással kiképzett légierősök inkább a stratégiai bombázásokat favorizálták volna. ${ }^{36}$

A légierő kezdetben a CEFEO északi és déli területi parancsnoksága területén szerveződött meg, majd 1950-től, az amerikai támogatások megindulásától kezdve hozzáláttak a hatékonyabb légi támogatást nyújtó kötelékek, a Harcászati Támadó- és Bombázócsoportok (Groupement Aérien Tactique d'Attaque et de Choc, GATAC) megszervezéséhez. A háború végéig négy csoportot hoztak létre Tonkin, Annam, Kokinkína és Laosz területén. ${ }^{37}$ Ezeket kezdetben főtisztek vezették, de mivel a szárazföldi erők régióinak és néha zónáinak parancsnokai tábornoki rendfokozatúak voltak, ezért később a légierő is tábornokokat bízott meg a vezetésükkel.

Ezen túl a légierő szerepe a müveletek során a hadsereg egyik fő mozgékony tartalékának, az egyre nagyobb létszámú és egyre nagyobb szerepet kapó ejtőernyősöknek a célba juttatásában és a logisztikai ellátásban a háború második felére meghatározóvá vált. Az útviszonyok és az ellenséges tevékenység szinte teljesen megakadályozta a közúti utánszállítást, ezért annak terheit is a végletekig leterhelt szállító repülőgépek vették át.

\footnotetext{
34 Jackson: i. m. 56-57.

35 Division Navale d'Assaut.

36 Shrader: i. m. 17.

37 Philippe L. Gras: L'Armée de l'Air en Indochine (1945-1954) - L'impossible mission. Paris, L'Harmattan, $2001,237$.
} 


\section{ÖSSZEGZÉS}

Elmondható, hogy a francia hadmüveleti vezetés rendkívül bonyolult rendszere miatt a legapróbb hadmüvelet megtervezésekor is mind vertikálisan, mind horizontálisan több vezetési szintet és törzset kellett bevonni, ami a müvelet sikerességét már annak kezdete elött nagyban korlátozta. Ez igaz volt mind az erőforrások megfelelő és hatékony csoportosításának kialakítására, mind pedig a vezetés egységének megvalósulására.

Ezt a helyzetet csak tovább súlyosbították a hadszíntér földrajzi sajátosságai, amelynek kiismeréséhez hosszú időre volt szükség, valamint a francia katonai vezetés heterogén öszszetétele, eltérö tapasztalatai és gyakran a hivatáshoz nem illő viselkedése.

Célszerünek tartom az egyébként komoly világháborús hadmüveleti szintủ és gyarmati háborús tapasztalattal rendelkező tisztikar tervezési és vezetési hatékonyságának további vizsgálatát, különösen a mozgó, támadó hadmüveletek esetében, amelyek általában a legnagyobb kihívást jelentik a törzsek és a parancsnokok számára. Különösen érdekes egy ilyen vizsgálat, ha a vezetők közötti érdekellentétek, vagy a rugalmatlan, a kialakult helyzethez alkalmazkodni képtelen, az eredeti elképzeléseikhez túlzottan ragaszkodók szemszögéből tekintünk át egyes müveleteket - például a Dien Bien Phu-i csata esetén a Castor hadmüveletet.

A francia haderő harcászati szinten rendkívül sok újdonságot alkalmazott nagy hatékonysággal a háború során - például a légideszant- és a folyami műveletek, vagy a közvetlen légi támogatás tökéletesítése, valamint a helyi törzsekkel együttmüködő különleges erök koncepciója -, illetve alkotott meg nagyon rugalmas szervezeti struktúrákat (ilyenek voltak a gépesített csoportok), de hadmüveleti szinten nagyon merevnek bizonyult.

Ez a merevség mind a területi alapon történő tervezés és az abból fakadó bonyolult aláés fölérendeltségi viszonyok, mind a haderőnemi és a személyes érdekekhez való túlzott ragaszkodás során tetten érhető, ami kihatással volt a hadműveletek sikerességére, ezen keresztül pedig fölerősítette a gyenge politikai és hadszíntéri katonai stratégia hibáit, amivel semmissé tette a francia katona és az oldalukon harcoló számos náció harctéri sikereit. A hadtörténelembe ezért az indokínai gyakorlatban megvalósuló hadműveleti tervezés és vezetés inkább figyelmeztető példaként vonult be.

\section{FELHASZNÁLT IRODALOM}

Allied Command Operations - Comprehensive Operations Planning Directive - COPD Interim V2.0. NATO SHAPE, 04. 10. 2012. https://www.cmdrcoe.org/download.cgf.php?id=9

Blythe, Wilson C.: History of Operational Art. Military Review, 11-12. 2018., 37-49. https://www. armyupress.army.mil/Portals/7/military-review/Archives/English/ND-18/Blythe-Operational-Art.pdf

Csikány Tamás: Az első világháború eseményei és hadmüvészete. ZMNE, Budapest, 2010.

Csikány Tamás: Az európai hadmüvészet a harmincéves háborútól a XIX. sz. végéig. ZMNE, Budapest, 2001. https://nkerepo.uni-nke.hu/xmlui/bitstream/handle/123456789/15007/cst_europai_ hadmuveszet_a_harminceves_haborutol.pdf;jsessionid=4B1B758FEC946D670F33FA5FD442 7CA5? sequence $=1$

DOD Dictionary of Military and Associated Term as of 2019. https:/www.jcs.mil/Portals/36/Documents/ Doctrine/pubs/dictionary.pdf

Doughty, Robert A.: French Operational Art - 1888-1940. In: Krause, Michael D. - Phillips, Cody R. (eds.): Historical Perspectives on the Operational Art. Center of Military History, United States Army, Washington, D.C., 2005, 69-108. https://history.army.mil/html/books/070/70-89-1/cmhPub_70-89.pdf 
Forgács Balázs: A második világháború partizánharcai és ellenállási mozgalmai Európában. Hadtudományi Szemle, 2018/3. szám, 45-67. http://real.mtak.hu/86888/1/18_3_hm_forgacs_balazs.pdf

Gras, Philippe L.: L'Armée de l'Air en Indochine (1945-1954) - L'impossible mission. Paris, L'Harmattan, 2001.

Horváth Csaba: Az 1940-es német-francia háború stratégiai-hadászati és hadmüveleti kérdései. Seregszemle, 2013/2-3., 279-291. https://honvedelem.hu/files/files/39133/seregszemle-2-3_internet.pdf Jackson, Peter D.: French Ground Force Organizational Development for Counterrevolutionary Warfare between 1945 and 1962. Thesis, Army Command And General Staff College, Fort Leavenworth KS, 2005. https://apps.dtic.mil/dtic/tr/fulltext/u2/a436931.pdf

Kier, Elizabeth: Imagining War: French and British Military Doctrine between the Wars. Princeton Studies in International History and Politics, Princeton University Press, 1999.

Krause, Michael D.: Operational Art Origins, Evolution and Application. A Forecast. In: Clayton, J. Thomas: Operational Art and Analysis. CMH, 1991, III-4-III-9. https://www.researchgate.net/ publication/232887426_The_evolution_of_Soviet_operational_art_The_significance_of_strategic_ defense'_and_'premeditated_defense'_in_the_conduct_of_theatre-strategic_operations

Life expectancy in France. https://www.ined.fr/en/everything_about_population/graphs-maps/ interpreted-graphs/life-expectancy-france/

Nguyen, Dong: Un peu d'histoire du Vietnam - CAP sur L'ANNAM. Capannam Travel. https://capannam. com/guide-pratique-vietnam/histoire-annam

Shrader, Charles M.: A War of Logistics: Parachutes and Porters in Indochina, 1945-1954. Foreign Military Studies. University Press of Kentucky, Lexington, 2015.

Windrow, Martin: The Last Valley. Dien Bien Phu and the French Defeat in Vietnam. Cassel, London, 2005. 